\title{
A Cytological Study on the Dog's Thyroid Gland.
}

\author{
Von \\ K. Takagi. \\ (From the Anatomical Laboratory of Osaka Mcdical College
}

(Prof. R. Tsukaguchi))

With 36 Figures (Plate XV-XVI).

Langendorff, Hürthle, Andersson, Bozzi, Galeotti, Müller and Lobenhoffer have the credit of having searched to a great extent for the relations existing between the histological structure and the secretory. activity of the thyroid gland.

Amongst others, the observations of Langendorff('89) are being quoted in many books even at present as authoritative statements on the histology of the thyroid gland. He was the first to examine closely the tissue of this organ, chiefly in its fresh state, but also in fixed materials with osmic acid solution, which he recommends highly. According to Langendorff, it follows that, differentiated according to their external appearance there are two kinds of follicular epithelium-cells, viz., the chief-cell (Hauptzellen) and the colloid-cell. The chief-cells are, in general, comparatively clear, occupying a greater portion of the wall of the follicle, and the protoplasm shows a sort of net-work, while it holds granules, which latter finding themselves accumlated . often in the part adjoining the follicular lumen sometimes form the "Körnchenzone." This kind of cell he considered as being in a state in which the cell has no secretion.

The colloid-cells as compared with the chief-cells are somewhat smaller in number and lie scattered in various places. Their characteristics are that not only is the protoplasm colored dark against osmic acid in the same manner as the colloid-mass which is the secretion of this gland (i.e. the colloid reaction), but it also takes the same color as the colloid-mass does against other kinds of coloring matter. This kind of cell was considered by him as being in a state in which the function of the glandular cell is at work, and he 
stated that the characteristics described above were nothing but the result of the accumulation of the secretion which was formed within the cells.

The two kinds of cells described above were, according to Langendorff, originally one and the same, but have undergone such a demarcation in their external appearance, simply because of the difference in their stage of secretory activity. And, besides, there is within the epithelium-cell another kind of cell which is extermely flat and whose cell-body gives a strong colloid reaction. Its nucleus has undergone a greater or less change: it is either withered or transformed. This phenomenon he termed "Schmelzung des Epithels" and he attributed it to a retrogressive change of the epitheliumcell, the cause of which being, according to him, the rise in the internal pressure of the follicular lumen due to the accumulation of the colloid-mass, and as it finally dies the follicle concerned either opens its mouth and is conglutinated with the neighbouring one or it causes the colloid-mass to flow out into the interfollicular lymphatic spaces.

Zielinska ('94), Hürthle ('94), Bozzi ('95), Schmid('96) and·Prévant('11) were on the whole in favour of the above-mentioned theory, though not without more or less difference in their opinions.

Hürthle ('94) found that after removing the greater part of the thyroid in many places of the remaining gland the chief-cells contained the " runde Masse" which assume a homogeneous appearauce. As this substance according to him has the same staining reaction as the colloid-mass existing in the follicular lumen, he considered it as droplets of colloid which makes its appearance within the cell as a result of accelerated cell activity. And, moreover, he often found in the sublimate fixed material a clear halo around this "funde Masse," but he attributed it to a phenomenon of shrinkage. He further stated that the cell which Langendorff mentioned as "Schmelzung des Epithels," should by no means be reckoned a retrogressive phenomenon but rather a living cell which was transformed from the colloid-cell, although at the same time he admitted the existence of an entirely different sort of retrogressive cell to which he gave the same term "Schmelzung des Epithels." That is to say, commonly speaking, in the epithelium-cell the nucleus first begins to produce a certain change, which is followed by the change of the protoplasm; then follows the colloid reaction, and, finally, the cell being 
entirely dead and broken up, is mixed up with the colloid-mass. He attached a special importance to this kind of change in the epithelium-cell, and attributed its appearance to "immere Vorgänge," deeming it a peculiar sort of secreting activity in the thyriod gland. And, accordingly, he stated that there are two secreting processes in the thyroid gland, one being found in the colloid-cell while the other is seen in the fact that the particular epitheliumcell dies by his "Schmelzung des Epithels," the broken pieces entering the follicular lumen as an ingredient of the colloid-mass.

Bozzi ('95) wrote to the effect that "Colloidsubstanz" first makes its appearance within the cell as a small granule which, increasing in size gradually, is accumulated in a portion where the cell faces the glandular lumen and then finally enters the glandular lumen to form the colloid-mass.

Andersson ('94) greatly differs from the foregoing authors in bis interpretations. According to Andersson, it follows that the afore-mentioned granules found in the chief-cell may be divided into two kinds along lines of coloring, one being the granules which are colored and the other those which are uncolored. He deemed these two kinds of granules the different secretions of the follicular epithelium-cell, and argued that the chief-cell sends out at the same time two kinds of secretion according to the granules held in it, viz., those which are colored and others which are uncolored, and these secretion-products being mixed up with one another within the follicular lumen form the so-called "colloid." In this manner, Andersson refuted the observations of Langendorff and others, and he deemed the structure of the chief-cell the principal secretory image of the thyroid gland, whereas the colloid-cell was taken for a cell which, being destitute of secretory activity, was on the verge of decay. Bruckner ('09) was on the whole in favour of Andersson's opinion.

Müller, L.R. ('96) differed from the foregoing authors in his opinion concerning the colloid-cell. He observed that the colloid-cell was, after all, produced as a result of the fluid content of the chief-cell having been drained into the glandular lumen, and that therefore this kind of cell should be the cell in its resting period.

The foregoing report of Andersson's researches may be taken as a valuable suggestion of the relations which exist between the granules held in 
the gland-cell and its secretory function; subsequently, Galeotti ('97), Ebner ('99), Erdheim ('03) and Lobenhoffer ('09) devoted themselves to the investigation of the granules.

Galeotti ('97) studied the thyroid gland of the turtle, under normal conditions, and under experimental injecting of various substances. As a result of his investigation of the cell-granules he distinguished from its staining resction two sorts of granules; one kind being fuchsinophil and of nuclear origin, they often range themselves in harmony with the longitudinal axis of the cell; the others assume the same colour as the colloid substance within the follicular lumen. Thus he identifies the latter with the coloring granules of Andersson and the colloid droplets of Hürthle. According to Galeotti, these two kinds of granules, as mentioned above, bave a quite different character and are drained from the epithelium-cells by a different mechanism into the follicular lumen, in which they mix up with one another and form the so-called " Colloidsubstanz."

Ebner ('99) divided the granules held in the cell chiefly in its fresh state into two kinds, one being intensely light-refracting and the other weak in light-refraction. The intensely light-refracting granules, chiefly found in the neighbourhood of the glandular lumen, are round in shape and varied in size, and are stained grey or dark brown with osmic acid, while those weak in light-refraction, greater in number than the former, are ball-shaped and are remarkably swall. And, moreover, he detected in Müller's fluid material a beehive structure and somewhat distinct "Längsstreifung." in the cell.

Erdheim ('03) further stated that the granules held in the cell, having a fatty nature, are scarcely found in the embryo and in the new-born child, but they gradually grow in quantity and size as the child grows and will never decrease, keeping in growth up to old age, so that it is possible that these granules have nothing to do with colloid secretion but are related to some unknown function of the thyroid gland which is undiscoverable even at present.

Lobenhoffer ('09), however, carrying out his investigations chiefly on a normal child found that colloids are produced from at least two kinds of granules which are formed within the epithelium-cell : one of them. having a 
fatlike nature denotes the granules detected by the foregoing authors and known as the coloring granules of Andersson, while the other has a fuchsiophil character. He further stated that the colloid-cell neither denotes a stage in which secretion is at its maximum nor a cell on the point of death, but rather a cell in its resting period, while the chief-cell denotes a cell which is full of mature secretion, that is to say a cell which has reached the height of its function. In this way he seconded Müller's opinion afore-mentioned.

By the cytological studies of recent years, plastosomes, being the chief component of all glandular cells, have come to be mentioned as being existent in the epithelium-cell of the thyroid gland. O. Schultze ('11) demonstrated chondriocontes in the mouse and Mawas('11) chondriocontes and mitochondries in the rabbit, and in this way it has been made clear that the arrangement of the thyroid glandular cell known since Baber ('76) as "Längsstreifung" has been, after all, caused by these plastosomes.

Benstey ('14,'16) studied the thyroid glands of various mammals, especially of the opossum, under normal and various experimental conditions. $\mathrm{He}$ found that, while in the part of the cell-body adjoining the follicular lumen the cell holds fat droplets, on the contrary in the outer pole (basal end) there are some mitochondrial filaments and vacuoles, which latter contain a dilute solution similar in its properties to the colloid of the follicular lumen, differing from this only in density. He deemed these unstainable contents of these vacuoles the true antecedents of the thyroid gland secretion which must be drained out from this side finally.

As far as I know, Baber ('76) is the first author who has written anything about the epithelium-cell in the interstitial tissue of the thyroid gland, and he termed it the "Parenchymzellen": its characteristics are that it decays easily. According to Baber it follows that these cells are first found in the interstitial tissue of the thyroid gland, and then passing through the epitbelial layer they enter the follicular lumen to form one of the chief ingredients of its contents.

Subsequently, Hürthle ('94) gave two kinds of interfollicular epithelium-cell, viz., those called the "Protoplasma-arme oder kleine Zellen" of nearly the same size as the follicular epithelium-cell and whose cell-body is 
remarkably granular, and others called the "Protoplasma-reiche oder grosse Zelleu," which having an extremely large cell-body, are similar to Baber's "Pareuchymzellen." The characteristics of these cells are the irregularity of their shape, being often found within the follicular epithelium. Hürthle stated that the large cells are closely concerned in the new formation and increase of follicles.

Loben hoffer ('09) subsequently stated that it was possible to imagine, from the fact that a great majority of interfollicular epithelium-cells hold granules, that they produce some substance between the intercellular spaces which serves as a stimulus for the new growth of follicles.

From the above-mentioned literature it will be found that there is quite an abundance of knowledge on the histological structure of the epithelial cell of the thyroid gland, and that as far as its structure is concerned the cell bears a very close resemblance to the externally secreting gland cell ; however, few of the investigators having entered upon the discussion of the functional correlation between all the cell-constituents, no theory is as yet established as to their secretory activity. Short as it is, the present treatise is intended to make some contribution toward making up this deficiency.

\section{Materials and Methods.}

Dogs of ages ranging from the third day post partum to two years old have been employed for my research works. For the fixing solutions I hive used :

a) Altmann's potassium bichromate-osmic acid solution ;

b) Levi's potassium bichromate-formol-osmic acid solution ;

c) Meves' modification of Flemming's solution ;

d) Benda's , " , " ;

e) Luna's potassium bichromate-formol-acetic acid solution;

and that the fixation might be accomplished with desirable speed and perfection it has been the practice with me to kill the animal with chloroform, and then, after injecting the modified Luna's fluid in its aorta immediately, to cut out the organ and dip it in the fixing solution above ref frred to. Passing 
through the regular process after fixation, the material has been imbedded in paraffin after being immersed in xylol and sections of 4,5 or $5 \mu$ were cut. As a treatment prior to dyeing, Rubaschkin's method bas been applied where osmic acid mixture was used. For staining I have employed Altmann's acid-fuchsin-picric-acid and Heidenhain's iron-alum-haematoxylin besides haematoxylin-eosin. Of all these methods the fixation with Meves' fluid and staining with iron-alum-haematoxylin have been used in most cases and brought good results.

\section{Observations.}

\section{The Chief =cell.}

Occupying the greater portion of the follicular walls their shapes are mostly cubical, though sometimes they are more or less columnar. Their cell-bodies are generally clear, and close to where the cell faces the glandular lumen are found somewhat remarkable terminal bars. I quite agree with the foregoing authors in that within the cell-body may be demonstrated at all times plastosomes, granules and vacuoles. However, on a minute examination of these important constituents of the cell-bodies it will be found that the mauner of their appearance and their numerical and distributive relations are extremely varied. That is to say, even although there is a general resemblance among the chief-cells, there is an infinite variety of structure in the individual cells, and this fact has caused me to infer that each individual cell showing a delicate struçtural difference of its own denotes a certain period of the glandular activity, and that a synthetic investigation into this infinite variety of structural images should provide a key to the door of the secrets of secretory function in the thyroid gland. Regarding it from this standpoint I have closely examined a great number of cells with an eye to the discovery of the greatest possible variety of structural images, and 15 figures (1-15) which I attach hereto have been drawn as being somewhat representative. How-

ever, between these different periods there are, as a matter of course, a number of intermediate forms, which, it should be needless to say, serve as a link between the different periods to make up the whole process of secretory activity. 
Figs. 1. a, and 2. Generally speaking, there is little enclosed within the cell-body, with the exception of Fig. 1. a, in which there is a small number of vacuoles in a portion where the cell faces the glandular lumen, that is, in the upper half of the cell, as is for the most part the case in my figures. The plastosomes appear abundantly in rows which mostly run in harmony with the longitudinal axis of the cell. They are in most cases either filar or longish rod-shaped with more or less curve. Besides, a small number of granular plastosomes (Plastochondria) lies scattered. The cell described in Fig. 2 bas no vacuoles. Some of the plastosomes, the chief component of the cell-body, are somewhat thick and, their surface becoming more or less coarse, they have a strong affinity for dye-stuff especially, some of these plastosomes making a stricture in several parts and even forming a distinct granularshaped chain when the stricture is at its maximum. At the same time are found some small granules, from whose external appearance it seems very likely that they are a product which has been separated from the granular chains. In short, it would appear that these figures show a period in which granules are scarce and the cell concerned is either at rest or in the earliest stage: of function.

Figs. 1. b, and 3. The cell holds a certain amount of secretory granules in its upper half, which granules being somewhat irregular in size run over from an extremely small size to a large one through a number of intermediate forms, the smallest of them being in perfect agreement witb the small granules shown in Fig. 2 in shape and coloring. The plastosomes are chiefly found in the basal part of the gland cell in quite large numbers, while they sometimes lie scattered in other parts, too. The cell in Fig. 3 has a small number of vacuoles within its cell-body, and the plastosomes are more or less weaker than the former in coloring, other things being about the same as in Fig. 1.b. In short, it seems that the cells described bere show the first stage of granular formation.

Fig. 4. The protoplasm in this cell is tinged somewhat darker than in the various cells described above, and the characteristics of the cell are that it holds a remarkably large number of well-grown and ball-shaped granules, being mostly of the same size with but a few exceptions in which the granules are extremely small. These granules get together chiefly in the upper part of 
the cell and make a zone, while in the basal part is found only a somewhat large number of remarkable plastosomes. This period shows the flourishing condition of granular formation.

Fig. 5. What is worth noting about this cell is that some of the granules held in it have a clear halo distinctly described around them and give themselves the appearance of the contents of a vacuole, and some of the granules of this kind having failed considerably in coloring are also reduced in size, whereas the haloes are of an enormous size and some of them present themselves as an entirely clear racuole destitute of granules. In Fig. 6 mearly all the granules are surrounded by such a halo as has been mentioned above, having in most cases failed in coloring and sometimes even running to the extreme of retaining a mere shadow of their own bodies. And, moreover, some granules having entirely lost their nucleus show themselves merely as clear vacuoles of various sizes, so that in this cell it will be found that the cell has undergone a remarkable change in structure and external appearance as compared with the various cells described above. The plastosomes give a longish filar sbape and the manner of their distribution is about the same as in the various stages mentioned above. While at the stage of Figs. 5 and 6 it is distinctly observed that the granules slowly undergoing a substantial change run over gradually to the vacuolar formation, and at the same time it cannot be doubted that the contents of the vacuoles must be equivalent to the change-product of the granules, viz., secretion.

Fig. 7. The cell-body is remarkably clear in its upper half, and is full of numberless vacuoles of various sizes, being mostly like a ball in shape. Those which are remarkably large have an irregular contour and there is a distinct trace of their having been conglutinated and joined to the neighbouring vacuoles. The plastosomes look like short rods in the intervacuolar spaces and are filar-shaped in the basal portion. Secretion is held abundantly in this cell and consequently it would appear that the cell is at the height of its activity.

The above statements have been based on a dog which is a little under 1 year of age, that is a dog which has almost reached its grown-up stage; however, in adittion to that, I have very closely examined dogs of various stages 
with an eye particularly to the histological structure as being affected by age, and the result has been that in the adult age the structure is nearly the same as above, though not without a slight difference in the puppy. For the sake of comparison, I give below my observations on a three-days old dog (Figs. 8-15).

Fig. 8. Within the cell-body there are many plastosomes and vacuoles, and the plastosomes are mostly longish filar or rod-shaped, though in the upper half of the cell there are some plastosomes with a remarkably rugged outline, giving them an appearance of a more or less granular chain, and the coloring is stronger than in the others. At the same time are detected plastochondria and minute secretory granules. The vacuoles are ball-shaped though their contour is generally indistinct.

Fig. 9. A great portion of this cell is full of clear vacuoles, which have a distinct contour and ball-shape of nearly the same size.

Fig. 10. The cell-body is remarkably clear and its internal structure is quite obscure. The plastosomes are nearly the same in shape as in the former, though their colouring is much weaker. Besides there will be found a small number of plastocondria and a somewhat large granule stained deeply, this latter being met with in the basal portion.

Figs. 11 and 12. Close to the base of the cell are found somewhat large granules of a yellowish brown colour, of more or less irregular sizes, which appear gathered together. Besides, there are plastosomes which are extremely weak in coloration.

Figs. 13, 14, and 15. These cells as compared with the foregoing cells have a more or less darker tone of coloration. In Figs. 13 and 14 the cell has a small number of remarkable filar plastosomes besides a few small granules and an extremety large one, which latter has a clear halo described around it. In Fig. 13 will be found besides this large granule an almost equally large clear vacuole and a large number of small vacuoles within the cell-body. Fig. 15 shows a part of the epithelium-layer of the follicular wall, and one of these three cells contains mostly small granules and the other two, vacuoles. The plastosomes are so placed that little difference is discernible between them and those in the foregoing cells, but the staining graduation of the nucleus is different and its internal structure is entirely obscure where stained intensely. 
On comparing the above observations on the puppy and those on the adult dog we find that the former widely differs from the latter in that (1), secretory granules are extremely scarce in it (2), on the contrary, it has a remarkable vacuolar formation, and consequently its cell-body is in general extremely clear (3), the constituents of the cell-body are mostly plastosomes and vacuoles, and that its structure is comparatively simple, all these conditions being kept up to the 6th month of birth.

According to literature on the relations between age and the structural change of the thyroid gland we find that Langendorff said as regards the form of the chief-cell that it is columnar during young age but is reduced in height as it grows in age and finally becomes almost flat when it reaches old age, while Erdheim stated that no granules are found in the upper half of the cell during puppyhood but they make their appearance only when the dog approaches its grown-up stage, increasing in quantity as it grows in age. However, according to my observations it follows that the height of the cell is extremely varied not only in the same age but even in the same material, also, according to the portion subjected to examination. And, as regards the amount of granules, it is generally small in the puppy and the contrary with the grown-up dog, as has been mentioned above ; however, we must not deny the fact that they are existent even in the extremely infant stage of the dog. Even in one and the same body of a grown-up dog we also experience that the granules are distinctly found or entirely absent according to the portion of the organ taken for examination. Therefore, I find that we may rightly say that the question of the correlation between the degree of granule formation and age is still open to discussion.

\section{The Colloid-cell.}

As has been mentioned above, it gives the so-called 'colloid reastion' and has a more or less remarkably dark tone. Compared with the chief-cell its number is much smaller and lies scattered between the former or exists more or less in groups. A minute examination of the structure has given us the fact that tha colloid-cell is also full of changes and in no case could it be treated in the same manner. Therfore, here again, following the example of 
my method in the case of the chief-cell, I have made out the following figures (No. 16-28) by selecting the important structural images out of various kinds of cells. However, in this case it is not so easy as in the chief-cell to connect the different figures and find out an imaginary order of secreting activity between them, therefore, I have confined myself to a diagrammatic explapation of each case as follows:-

Fig. 16. The enclosures of the cell-body are a small number of nearly equal-sized small granules and a small number of clear vacuoles which are larger than the granules. The plastosomes appear in a remarkable manner and, being irregularly arranged tbeir shape is mostly like a long rod, getting together in large numbers in one corner of the upper half. The terminal bars are distinctly observed.

Fig. 17. In the upper half of the cell are remarkably large numbers of granules of irregular sizes, ranging from a small size to a remarkably large one. At the same time is found a small number of vacuoles, of which some having lost a portion of their partition-wall bave an exceedingly irregular contour, which causes us to imagine that the vacuoles concerned have been conglutinated and joined to their neighbours. A great majority of the plastosomes are found in the basal portion, only a small number of them being met with in the upper half.

Fig. 18. The intensive coloring of the protoplasm makes it to some extent difficult to get a distinct impression of the internal structure of the cell; however, the granules and plastosomes are visible, of which the former having various sizes are remarkably great in number, getting together in the upper half of the cell-body to form a wide zone. The plastosomes are longish filar in shape and are found mostly in the basal portion, running nearly in harmony with the longitudinal axis of the cell.

Fig. 19. The exceeding concavity of the cell at both sides and the inner surface makes it inevitable for the cell to give itself a peculiar form, with its four corners projecting tremendously. The protoplasm having a dark tone, it is difficult to investigate the internal structure of the cell-body; however, in the upper half of the cell are found large granules of nearly the same size, which make that portion stained strongly dark, whereas in the basal portion 
of the cell is found a remarkable nucleus with filar or rod-shaped plastosomes around it.

Fig. 20. The cell-body being stained in a high degree, it is no longer possible to discriminate its internal structure, though by using great care we can observe something like granules in its upper half.

Fig. 21. The strong concavity of the cell at both sides causes one of its four corners which faces the glandular lumen to extend itself in a long and slender form, while the opposite corner in the basal portion is also more or less extended, thus giving the cell a curious aspect of holding the neighbouring cells in its arms. The greater portion of the cell-body is stained dark, though somewhat light in various places. There is nothing to be observed as to its internal structure; however, by following up the serial sections I have been able to prove the existence of a normal nucleus in this cell. In Fig. 22 are found two cells in the middle which are of nearly the same structure as the former though they are remarkably flattened in form. They are entirely stained dark and it is difficult to ascertain their contents, though in one of them is distinctly found a nucleus. These two cells exactly remind us of the "Schmelzungs-zellen" of Langendorff. Next to them are found a clear chief-cell on the one side and a dark colloid-cell on the other, which cells having a proper structure of their own hold the former between them and form a marked contrast with one another.

Figs. 23 and 24. Both these cells have a dark colour, having within the cell-body chiefly granules in one cell and vacuoles in the other. The condition of the plastosomes, is, in general, common to the colloid-cell, though the coloring of the nucleus being abnormally intense it is difficult to describe the internal aspect of the nuclear network. The terminal bars are remarkable.

The above observations have been based on a one-year-old dog, that is a dog which has reached its full-grown stage. Below I give a little explanation on Figs. 25-28 which have been obtained from a three-days-old puppy :-

All these cells have protoplasm which has a more or less remarkably dark tone, and yet, since their outline is generally concave both in flank and the inner surface they. acquire a peculiar form and are therefore distinctly discriminated from the chief-cell. They are the same as in the colloid-cell of a grown-up dog in that the cell-body holds plastosomes, granules and vacuoles. 
Ifowever, the coloring of protoplasm being generally weak in the puppy it is comparatively more easy to discriminate the internal structure of the cellbody.

After all, colloid-cells agree with chief-cells in that they have, as constituents of the cell-body, plastosomes, granules and vacuoles; however, it must be noted that the morphological correlation between them, particularly between the granules and vacuoles is not so clear as in the chief-cells. The reader's attention is drawn to this point, now, because, as will be dwelt upon later, I am convinced it has a very important bearing upon making a functional demarcation between the colloid- and chief-cells on the occasion of considering the activity of the colloid-cell. Then, as regards the difference of colloid-cells as affected by age, it will be noted that the colloid reaction more or less differs as ages vary. Generally speaking, there is nothing particular to be noted save for the fact that it is low in the young animal but it becomes gradually high as it advances in age. It is worth noting, however, that a majority of colloid-cells have a curious shape of their own by the concavity of their border-lines, some of them running to the extreme of being flattened in a high degree and at the same time giving the highest degree of colloid reaction. However, there are always a normal nucleus and no indications of death and break-down. And, further, it must be noted that in general no cells recognizable as undergoing perbaps any particular retrogressive change have been met with in the follicular epithelium. Besides, with all possible care no mitosis has been proven.

\section{The Interfollicular Epithelium-Cell.}

The interfollicular epithelium-cell exists in the interfollicular space, and it sometimes forms a group of cells which is entirely separated from the follicular wall or is found in close relation to the epithelium of the follictlar wall. And, not infrequently, the cell exposes itself directly in the glandular lumen, a portion of it being sometimes wedged in between the follicular epithelium cells. A wide difference exists between the adult and new-born dogs in their histological structure. Take the adult dog first (Figs. 29-32), and it will be found that in general the cell-body is remarkably large and is 
irregular in shape. The border-lines of the cell are sometines indistinct, though in othor cases thry are distinct and divided by a remarkable space. And, although it seems likely that the appearance of this space may be taken for a proof of the intense shrinking property of the cells concerned, I would argue, from the fact that this space may be demonstrated even when there is no hitch about the fixation of the cell, that it would be in order for us to deem it rather a natural image than to consider it as an artificial product due to cell-shrinkage. As in the case of the follicular epithelium, the formative constituents of the cell-body are, (1), plastosomes, (2), granules aud (3), vacuoles ; however, a minute examination of these elements shows that they greatly differ from the follicular epithelium, as will be noted below :-

Fig. 29. The plastosomes are threads in shape or rods either longish or short, and are arranged in irregular rows, some of them even having one end swollen up and stained in a more or less high degree. Between these plastosomes lie scattered extremely small or somewhat larger colored granules. The smallest of the latter being almost the same in coloration and size as the swollen-up end of the plastosomes described above, it is difficult to discriminate them from one another.

Fig. 30. The plastosomes being extremely weakly stained barely leave their shadow. On the other haud, however, the granules are remarkable in their appearance, and their size and forn are varied in the extrame, the smallest of them being nearly the same as those found in the foregoing figure . and extend to much larger ones through various intermediate sizes. These granules are generally round in shape and there is a difference in their nuance. What is peculiar about these granules is that, with the exception of the smallest, they are very wëak in coloration in the central portion and for that reason have that portion always clearer, while only the cortical zone of the granule is dyed dark and as a result makes manifest a peculiar annular formation.

Fig. 31. In the cell-body are held a large number of granules dyed dirk in the cortical zone but they are only such as have been observed in the foregoing figure. Their form and size are varied, though they are in most cases round or oblong. Besides these dark-dyed-annular formations there is a large number of extremely remarkable vacuoles. 'The size and form of 
these vacuoles which are nearly like the annular granules are extremely varied. The plastosomes are very few in number and are shaped somewhat like longish threads, though in the proximity of vacuoles they look like short rods.

Fig. 32. This cell is a little different in shape from the various cells described above, with comers remarkably rounded off and intercellular spaces particularly broad. As is illustrated by the figure, the cell holds numberless vacuoles of nearly equal size. Besides vacuoles are found annular formations of various sizes, a few very small granules and a small number of plastosomes.

The above observations have been based on a nearly adult dog, a little less than one-year-old, and yet I have been able to detect for the most part the same structure in adult dogs, also.

It would appear that even in the interfollicular epithelium-cell the principal constituents mutually show a definite genetical relation between one another. That is to say, although I could not make it directly clear that the plastosomes do gradually transmute into the original substance of granules and that by its separation they form independent colouring granules, from the similarity existing between the granules and the swollen up extremities of plastosomes both morphologically and in point of colouration, I am convinced that it would not be altogether unreasonable to infer the above-mentioned genetical correlation between the two. Then the substance of colouring granules slowly begins to transmute particularly in the central portion and thus gradually passes into transparent liquid as a vacuolar content. In this way, the cell presents an alveolar structure of high degree for a certain period: Now, on comparison of these points with the foregoing observations on the follicular epithelium, it will be found that, however apparently different they may seem in their form, size and structure, yet histologically speaking there are points of uniformity which are common to these two kinds of cells. In other words, it may be stated that, as is experienced in the follicular epithelium, the various histological structural images which make their appearance in the interfollicular epithelium are entirely influenced by the morphological changes which are undergone by the constituents, and more 
especially the colouring granules, of the cell-body, and that these points of histological resemblance between the two cannot but suggest a functional resemblance between them.

On the other hand, it will be found that in the 3 to 5 -days-old new-born dogs the interfollicular epithelium-cell is small and holds as its constituents plastosomes only. The latter are chiefly short and rod-shaped and an infinite number of them fill the larger portion of the cell-body. Besides these, there are neither granules nor vacuoles to be found (Fig. 33). Therefore, it follows that in the new-born dog the structure of the interfollicular epithelium-cell is very simple and has peculiarities of its own which are easily discriminated. Fig. 34 shows what exists within the follicular epithelium, and everybody will easily admit that looked at from the point of view of its form and structure, it cannot be classed with the follicular epithelium-cells whatever its position may be.

The above-mentioned conditions of the interfollicular epithelium-cell in the new-born dog continue for a very short period only and, already on the 22nd day of birth a part of it undergoes a greater or less change, that is to say the cell is somewhat grown up in size and the number of plastosomes is reduced considerably. Such cells gradually increase in number and on the 38 th, 39th and 48th days of birth they become much greater in number than those which are in new-born dogs. And, besides, there are within the cellbody a small number of small granules and quite a large number of vacuoles of a somewhat larger size. And, at this stage, it will be observed that the appearance of intercellular spaces is remarkable. Then, in the two-months-old dog, cells which are full of plastosomes in new-born dogs are only found scattered here and there, the majority of cells having a smaller number of plastosomes. Within the cell-body of the latter there are a small number of annular formations, besides somewhat longish and more or less thickened plastosomes, small granules and a great number of vacuoles. So it will be seen that at this period the dog has nearly reached the adult condition. In the following periods it will be seen that age has little appreciable to do with the histological conditions of the cells, though in an almost one-year-old adult dog it is worth noting that as mentioned above the appearance of coloring granules and vacuoles is tolerably remarkable. 
In short, I may state that, as quoted above from the literature on the subject, I can distinguish two kinds of cells showing an entirely different structure in the interfollicular epithelium-cell. The one is chiefly found in the new-born stage only and its cell-body is simply filled with plastosome, without any such material contents as granules or vacuoles, while in the other the cell-body is larger than in the former and as if grown by its transformation; the number of plastosomes gradually decreases thus giving place to such constituents as granules or vacuoles instead. This kind of cell is found in somewhat large numbers already in about three weeks after birth, and the number of them increases as the dog grows in age, while the cells belonging to the former entirely go out of existence by degrees. From these facts we may infer that the one is functionally still infant, while the other is showing its function.

\section{Summary.}

Go over my observations given above, and it will be found that in general they agree with those of the senior authorities in that within the cell-body of the epithelium-cell of the thyroid gland are held as its principal histological components plastosomes, granules and vacuoles, and that the existence of the so-called 'colloid reaction' marks the difference between chief- and colloidcells among the glandular cells.

First of all, it may be said that the above-mentioned components of the cell-body have by way of a certain morphological change a most intimate relation with one another in their formation. That is to say, it seems that at a certain period the plastosomes first become somewhat fat and thick and grown in colouring, while at the same time they become zig-zag in contour, the rod-shaped or filar plastosomes which originally had a smooth-surface gradually passing in this way into the granular threads, as if they consisted of a chain of tiny granules, which being disintegrated would produce independent small granules (Fig. 2). That the tiny granules so-separated and produced from the plastosemes are responsible for the genetic origin of the secretory granules of the thyroid gland-cell might. be easily recognized by everybody from the existence of a large number of intermediately growing 
transition types by which they are connected with one another (Figs. 1. $b$, and 3). From this point of view plastosomes after all could not but be the genetic substance of secretory granules. Be that as it may, the secretory granules produced in this way mass in great numbers in the upper half of the cell for a certain period and make the so-called 'Körnchenzone' (Fig. 4). And these granules are nothing else but the coloring granules, which have been equally acknowledged by various authors.

$\because \quad$ Now, as they accomplish a certain degree of growth, the granules gradually describe around themselves a clear balo, which it is deemed possible is due to the separation of a watery transparent liquid substance around the granules probably caused by a certain chemical change of their own substance. And, as they make progress in their change, the granules become gradually. smaller in size and weaker in coloring in inverse proportion to the clear haloes which become thicker and more distinct, and the last thing to be noticed of the granules is clear vacuoles which supersede them after their perfect consumption. In fact, these are the granules termed by Andersson " chromophobe Sekretkörner" (Figs. 5 and 6).

According to these facts it would follow that the content of a vacuole is undonbtedly a tranismuted product obtained through the substantial change of the granule itself, i.e., the secretion of the gland-cell. In this way, a greater portion of the cell-body of a gland-cell is for a certain period filled by vacuoles as substitutes for granules (Fig. 7). This exactly shows a state in which there is abundance of secretion.

By the delicate histological changes of the gland-cell described above, I believe I have been able to get a general outline of the secretory function of the thyroid gland. And, the most important of all in the secretion formation are the substantial changes of the secretory granules; and the manner in which the granules undergoing a gradual change pass into secretion, that is the content of vacuoles, deserves our special notice as being a morphological expression of secretory function in the thyroid. gland. In other words, the secretory process of this organ, regarding it from the morphological standpoint, amounts entirely to a history of the changes which take place in the secretory. granules, so that from this view-point there is no difference what- 
ever between the thyroid gland and the common externally secretory gland, and more especially I find a strange similarity, indeed, between the secretion phenomenon of the thyroid gland and that of the pancreas, of which I gave an account in 1920. This fact must be noted down here conspicuously as a proof of the absence of particular demarcation, along lines of histology, between the internally and externally secretory glands.

The above statements have been based chiefly on the chief-cell of the thyroid gland, especially in the nearly adult state, and, therefore, according to the above-mentioned observations it would follow that the cell is performing its functions in a most active mamner and it would be entirely unreasonable to deem it a cell which lacks secretion. In this respect, I side with the views of Andersson and Lobenhoffer.

As it is generally the rule with the chief-cell that as its constituents at the new-born stage are chiefly vacuoles with very few coloring granules (secretory granules) to be detected, it nay be inferred that its functionary conditions somewhat differ from those at the adult stage.

In the colloid-cell plastosomes, granules and vacuoles are held as constituents of the cell-body, and consequently, on a first consideration, it would appear reasonable to admit in it the existence of the same functions as in the chief-cell; however, on a still closer examination of the two in point of structure, I have been able to point out a most important difference between them which must not be overlooked. In the colloid-cell, namely, the components of the cell-body always retain a certain form, and it is very seldom the case that the traces of any connection or running over between them are noticed. In other words, it lacks the important morphological change which could be regarded as a sign of secretory functions in it. That is to say, the plastosomes have always a typical form and there are no signs of granule formation in them, while the secretory granules, also, mostly stop at a certain degree of growth and they have no tendency to grow up any further to pass into a secretion formation. And, moreover, as the colloid reaction becomes high, the substance of the granules, instead of showing vacuolar formation, being conglutinated and joined to the intensely colouring protoplasm run over to a strongly dark-stainirg homogeneous mass (Figs. 20 and 21). Though 
they appear, the vacuoles have comparatively indistinct border-lines, and, as the colloid reastion progresses, they appear only seldom, and finally go out of existence entirely (Figs. 16-19).

From the above facts it may be rightly inferred that the secretion activity of the colloid-cell is either very weak or is almost entirely absent, and, if that be really the case, there will be a problem to be solved with regard to the significance which the components of this cell have functionally. Now, it has bəen equally acknowledged by every senior investigator that the demarcation between the chief-and colloid-cells simply points to thier function and that they are not altogether different kinds of cells. I have also given this point special attention and have been able to ascertain the fact that both cells are connected with one another by a number of intermediate transitional types between which and the former it is difficult to establish a sharp demarcation, according to the degree of colloid reaction and internal structure. The cells in Figs. 12-14 have been placed, in view of their structure, under the category of chief-cell, though they bear a close resemblance to colloid-cells in that they have a slightly dark tinge in common. Therefore, according to my observations, it would seem possible that the colloid-cell is functionally connected with the chief-cell and the latter, tending by degrees to decline in activity, gradually runs over to the former. Therefore, the colloid-cell is either already poor in its power of secretion formation or lacks it in its entirety, and the components held in it stay there, after all, only as remnants of those of a cell which has been at the height of its activity i.e. chief-cell. Therefore, if it is permissible to discuss the function of the colloid-cell by regarding it from the histological standpoint mentioned above, it would follow that it simply works to drain out of the cell-body by degrees secretions (vacuolar content) which have been produced within the body in the past. And, besides, as a proof of the lack of functional activity in the colloid-cell, I would point to a peculiar form in which the cell appears consequent upon the constant pressure upon it of the adjoining chief-cells or content of the follicular lumen. This cannot but be the result of loosening of a stretched cell-body as its function declines. In any case, the colloid-cell gradually drives out of itself the content of vacuoles, and, as its granules are, also, gradually lost in remarkibly dark-staining protoplasm, its cell-body is usually 
shrunk and flattened in a high degree and thus gives the follicular epithelium a peculiar appearance (Figs. 22 and 28 , Langendorff's Scimelzungszellen!), However, even at this stage the nucleus of the cell, as always, retains its nomal condition and the plastosomes in most cases are distinctly noticed within the cell-body. From these facts it may be stated that at this period the cell is by no means dead, though it would be easily admitted that the cell is functionally entirely at rest. In some cases the cell nucleus is staiced dark, and in others the darkness is so extreme that its internal structure is entirely covered (Figs. 15, 23 and 24). It is difficult to answer what this means functionally. Howerer, at no period of cell-function, have I anywhere at all come across a state in which the gland-cell, dead and broken up, is directly intermingled with the content of the follicular lumen. Therefore, as far as ny examination goes, I doubt the existence of a phenomenon called "Schmelrung des Epithels," no matter whether it be in the sense of Langeudorff or in that of Hürthle. And, although I could not positively prove whether or not the cell, after a certain period following the height of functional rest' reached by it, again becomes a chief-cell and repeats its function as such, the fact that, excepting in the new-born stage, no mitosis could be proved in the follicular epithelium, should establish the truth that a deathphenomenon of the epithelium-cell occurs very seldom.

Aud, although it has been written that cell-elements sometimes find themselves mixed up in the colloid-mass, I have not been able to prove the origin and nature of such a cell within the scope of my studies.

I admit also that the histological structure of the thyroid gland-cell more or less differs according to its age. Geverally speaking, the appearance of granules is seldom experienced in the new-born stage, vacuoles being the chief element. However, the granules gradually increase in number from the seventh or eighth month after birth, and at the adult stage (about 1 year after birth) they reach the above-mentioned state. And, in my examination of dogs up to two-years-old I have not been able to find out that the granules increase any more according to age. After all, it will be noted that, as mentioned above, the appearance of granules is influenced by the secretion stages, and that it is different even at the same age. Moreover, according to my experi- 
ments, the granules are different in number even in the same organ according as the portion taken for investigation varies. It is, therefore, a very hard task to judge the number of granules absolutely.

In the next place, I will discuss the interfollicular epithelium. In this kind of cell it will be found that the structure is quite different according as it is in the new-born or other stage. That is to say, in the new-born dog the cell is suall and as its constituents it holds plastosomes only, there being no particular function to be seen in its structure. With the lapse of time, however, some cells become larger and the plastosomes decrease in number and, over one month after birth the cell-body holds as its chief component colouring granules and vacuoles besides plastosomes, and, exactly the same as in the case of the follicular epitbelium, it will be experienced that the various structural changes shown by them indicate the existence of the closest formative relation between all these components. And, should it be the case that these changes reflect the functions of the cell concerned, it would not be wrong to consider that, looked at from the histological standpoint as mentioned above, this kind of cell, just as the follicular epithelium, belongs to a certain glandular cell and has secretory function. And, though it would be superfluous to state that even in this case the content of vacuoles represents the secretion, it will be found that the manner of its formation is different from that in the follicular epithelium. That is to say, in the latter, granules having a clear halo around them were, as observed above, the chief images of the secretion formation, but, in the former, instead of them, a peculiar annular formation apears as its characteristic feature. In this way, it would be easy to acknow-. ledge that, regarding them from the forms of the secretion formation and therefore probably from the nature of the secretion, the two are not the same. And, as regards the way in .which secretion is discharged and absorbed, it would appear that it. finds a reservoir for a certain period in the intercellular space, though we are left in the dark as to whether the secretion so. stored up there is thenceforward absorbed directly in the interstitial lymphatic space or whether after being discharged into the follicular lumen it constitutes an element of the colloid-mass. However, we can say this much, as Hürthle said, this kind of cell often wedges itself in the rows of the follicular epithelium 
and is placed directly face to face with the follicular lumen, and, from this fact it will follow that undoubtedly at least a part of the secretion is drained cut into the follicular lumen.

Immediately after birth, the interfollicular epithelium-cell is small and its body is filled with plastosomes only. Neither granules nor vacuoles are to be found in it. However, about three weeks after birth, there are many cells in which the various forms of constituents named above appear. On this score, we may assume that the interfollicular epithelium-cell begins its activity at this stage already.

Lastly, a few words about the colloid reaction. According to my observations mentioned above, there is no doubt about the fact that the secretion of the thyroid gland is chiefly produced from the chief-cell. And, although it is difficult to answer why the content of the vacuoles in the chief- and colloidcells which is always watery transparent instantly gives a characteristic colloid reasion once it is drained out into the follicular lamen, there are at least two presumptions which make it possible to trace its cause. One of them is the hypothesis which claims that the vacuole content of the glandular cell when or after flowing into the follicular lumen suffers another chemical change. The other presumption is the hypothesis which assumes that the secretion of the follicular epithelium changes its nature by reason of its mixture with that of the interfollicular epithelium-cell. It must be left to later investigation to . judge of the correctness of these hypotheses.

In fine, the osmophile character of the colloid-mass is, as is well known, always different in its degree, and this is also the case partially not only within one and the same organ but also in the very. same follicle. It may be said that these phenomena prove that the colloid-mass has not always the same quality but differs according to time and position.

That the reaction shown by colloid-cells upon osmic acid is not in the vacuoles, which are the secretory contents of the cell, but is rather always in the protoplasmic part, coupled with the fact that the reaction is still more remarkable always in an apparently shrunk cell, which is either short of or is entirely wanting in such actively formed constituents of glandular cells as secretory granules or vasuoles-these facts demonstrate that not only is there 
no correlation between this reaction and the cell-activity, but rather the two are contrary to one another. This is the reason why my interpretations respecting the functions of the cell are entirely different from those of Langendorff.

Now, opinions with ragard to the way in which the follicular luwen when full is drained of the secretion, may be reduced into the following three classes : those which say (1), that it is due to a physiological destruction of the follicular wall, (2), that the secretion passes through the intercellular spaces of the follicular epithelium, (3), that it is drained by osmotic penetration through the epithelium-layer.

With regard to the first opinion, it was advocated by Biondi, Langendorff, and Hürtble. Biondi ('88) maintains it in that when a follicle has reached a certain growth, the epithelium-cell partially flattens and at last vanishes, thus allowing the colloid to be poured into the lymphatic system. Langendorff ('89) asserts that the secretion is drained out of the follicular lumen through a damaged part of the follicular wall caused by his "Schmelzung des Epithels," and Hürthle ('94) comes to the same opinion too, his "Schmelzung des Epithels," however, having a different meaning as mentioned above.

Then, intercellular spaces have been termed "Intercellulargünge" by $\mathrm{Hürthle}$ who is at the same time one of the chief upholders of the second opinion. He observed that Berlin blue injected into the lymphatic space comes out in a form of "blaue dünne Fädchen" existing between the epithelium-cells, which are considered by him as a coloring matter filling the intercellular spaces. And, after removing the greater part of a thyroid gland he frequently found a linear substance between the epithelium-cells in the remainder of the gland. This substance, according to him, is stained just as the follicular content : he therefore termed it "Colloidstränge," and attributes its appearance to a result of colloid substance having entered into the "Intercellulargänge." Accordingly, he is of the opinion that the follicular content is carried partly through the "Intercellulargänge," and partly through a destroyed part of the follicular wall. And, Zimmermann ('98), while examnining "Kittleistennetz" in various kinds of glandular epithelium-cells, was able 
to prove this net even in the thyroid epithelium. This is a hexagonal net aud, what is peculiar about it is, that it lacks " Kitt" at the crossing-points, which is caused, according to him, possibly because the cells have separated from one another in order to give passage to the secretion. Matsunaga ('09) has also observed, by applying a lymphatic injection, the existence of the so-called "Intercelluläre Lymphgänge" and stated that the colloid must be drained out chiefly through these "Lymphgänge" which are found between the epithelium-cells. The findings of Zimmermann and Matsunaga make a valuable contribution in support of the second opinion aforementioned.

As to the third opinion it is a result of Lewandowsky's reasoning. To my regret, I have not been able to come across his original report; however, from what is quoted in Biedl's works, I find he regards the follicular content as penetrating the epithelial layer rather by means of osmose.

Recently, Ferguson, Bensley and Maurer expressed quite a different opinion from the foregoing. Ferguson ('10) believes that the secretion may either be discharged from the chief-cells into the lumen of the follicles, or from the cells directly into the lymphatic vessels. Bensley ('14 and '16) claims that the secretion of the thyroid gland is made in the form of vacuoles near the outer pole of the follicular epithelium-cell, and, as already mentioned, it is a dilute solution and similar in its properties to the colloid existing in the follicular lumen. This secretion is excreted under normal conditions from there directly into the interfollicular vascular channels, which is termed by him the direct mode of secretion. When once the adjustment between the functioning of thyroid gland and general body conditions is disturbed, as is the case in a hyperplastic gland of an opossum and a human gland attacked by Basedow's disease, the rate of secretion is raised in excess. The secretion is then partly condensed and makes its appearance near the base of a cell-body as intracellular colloid droplets. These latter migrate by degrees towards an inner free surface and are there discharged into the lumen, in which it is stored. That is his indirect mode of secretion. Maurer's view ('17) seems also in the main to be in accord with this.

As far as my examination goes, I have been able to recognize, as aforesaid, neither such a case of destruction of a follicular wall as described by 
Biondi, nor any gap, nor breakage of epithelium which would be caused by the "Schmelzung des Epithels" in the sense of Langendorff or of Hürthle. On the other hand, I have recognized what Zimmermann observed as regards the terminal bars. In a dog's thyroid they are also almost always existent between the epithelium-cells, so that the follicular lumen is enclosed strictly; notwithstanding this, on a tangentially cut section of a follicle I have been able to confirm that "Kitt" is always lacking on every crossing-point of a net of terminal bars.

In the face of such a fact, it will be possible to infer that, although I have not been able to prove microscopically the "Intercellulargänge," the follicular content first finds its way into the intercellular spaces in order to be drained out of the lumen.

According to studies on the chemical nature of colloid, there are many ingredients which have been known as important, such as "Thyreoproteid" (Notkin), “Jodthyreoglobulin" (Oswald), “Jodthyrin" (Baumann), "Thyroxin" (Kendall), etc. In respect of their physical nature permeability has been, in some of them at least, well confirmed. Therefore, Lewandowsky's theory of osmose should not be rejected as being altogetber faulty. As regards the theory of Bensley, it would be difficult to unhesitatingly compare his observations with my own, as the animals used as materials and the technique employed by him are different; however, I quite agree with him in that the content of vacuoles should be regarded as a secretion of the thyroid. It should none the less be noted that in my case the vacuoles appear almost always in a part adjoining the follicular lumen, and never in an outer pole near the base, as was the case in Bensley; therefore, I have no grounds on which to support his direct mode of secretion, so I can not say anything about the intracellular colloid-droplets, as I have not made the same experiments as Bensley.

\section{Conclusion.}

1. The secretion activity of the thyroid gland is chiefly done by the chief-cell. The structure of the chief-cell bears the closest resemblance to the common externally secreting gland-cell in that it has as its chief constituents 
of the cell-body, plastosomes, granules and vacuoles, and, since at its secreting process they respectively display a delicate change by which it is shown how they are morphologically very closely related with one another, it wuuld not be a difficult task to ascertain morphologically the real mamer of the secreting process of the thyroid gland by following up these changes. And, at the time of the secreting process, the most important part is played by secretory granules whose origin goes back to plastosomes, and the tiny granules so separated and produced from the latter, after attaining a certain degree of growth and size become the secretory granules. Then such secretory granules after a certain period slowly undergo substantial chauges and finally are transformed into secretion (vacuoles). Anyhow, from the purely morphological point of view the minute secretory conditions of thyroid coincide with those of the dog's pancreatic cell, of which I gave an account before.

2. The colloid-cell resembles the chief-cell in a certain degree in the structure of the cell-body ; however, generally speaking, in the constituents of cells, especially secretory granules, some important morphological changes are , lacking, which make it possible for one to consider them as participating in secretory function. This demonstrates the fact that a retrogression of secretory function is taking place in the cell concerned and, in some extreme cases it will be found that the function is entirely at quiescent. In short, the secretory granules and vacuoles of these cells sbould be regarded as having no direct functional significance, but as staying behind simply as a remnant of functional structure in the past.

3. The colloid-mass, which is stored in the follicular lumen as secretion, is drained out probably through the intercellular spaces.

4. That secretory granules of the thyroid are scarce at the new-born stage and are plentiful at the adult stage does not mean that secretory function is weak in the former and increases in strength in the latter. It is simply a difference of secreting conditions which exists between the two, looked at from the morphological standpoint. Even at the same adult stage, there is a marked difference in the amount of granules which appear. Such difference is brought about chiefly through the difference in the secretion-stage of the orgaus subjected to examination and, in no way can it be taken as indicating the age of the subject. 
5. The interfollicular epithelium of a new-born dog differs in structure from that of dogs of other ages. In the new-born dog the cell is mostly small and has, as formed constituents of the cell-body, plastosomes only, besides which not a single granule or vacuole is to be detected. However, in three weeks after birth and thereafter it is large and bolds, within the cell-body; the various constituents named above. Looked at from its structure, this large cell can also be reckoned as a kind of glandular cell, and its conditions of secretion are somewhat different from those in the follicular epithelium-cell. It is possible that the secretion of this large cell is shot forth directly into the interstice, although from the fact that it often finds itself wedged in the epithelium-layer it can not be denied that at least a portion of it is drained out into the lumen.

In conclusion, I must express my deep sense of gratitude to Prof. R. Tsukaguchi, who has led me earnestly and kindly while engaged in this work. 


\section{Literature cited.}

Andersson, O. A., 1894. Zur Kenntnis der Morphologie der Schilddrüse. Arch. f. Anat. u. Phys. (Anat. Abt.).

Baber, E. C., 1876. Contribution on the minute anatomy of the thyroid gland of the dog. Philosophical Transactions, Vol. 166, Part II, cited from jahresberichte über die Fortschritte der Anatomie und Entwicklungsgeschichte.

Bensley, R. R., 1914. The thyroid gland of the opossum. The Anat. Record, Vol. 8.

Bensley, R. R., 1916. The normal mode of secretion in the thyroid gland. Amer. Journ. of Anat., Vol. 19.

Biedl, A., 1913. Imnere Selkretion, 2te Auflage, 1 ter Teil.

Biondi, 1888. Beitrag zur Struktur und Funktion der Schilddrüse. Referat in der Berliner klinischen Wooheuschrift, $\mathrm{Nr}$. 47, cited from Hürthle.

Bozzi, E., 1895. Untersuchungen über die Schilddrüse. Beiträge zur path. Anat. u. zur allg. Path., Bd. 18.

Bruckner, J., 1909. Sur la secretion thyroidienne. Compt. rend. Soc. biol. Paris, T. 66.

Ebner, V., 1899. Von der Schilddrüse. Kölliker's Handbuch der Gewebelehre des Menschen, Bd. 3.

Erdheim, J., 1903. Zur normalen und pathologischen Histologie der Glandula thyreoidea, paratliyreoidea und Hypophysis. Beiträge zur patb. Anat. u. zur allg. Patb., Bd. 33.

Ferguson, J. S., 1910. The anatomy of the thyroid gland of elasmobranchs, with remarks upon the hypobranchial circulation in these fishes, Amer. Journ. of Anat., Vol. 11.

Galeotti, G., 1897. Beitrag zur Kenntuis der Sekretiouserscheinungen in den Epithelzellen der Schilddrüse. Arch. f. mik. Anat., Bd. 48.

Hammersten, 1910. Lehrbuch der physiologischen Chemie.

Hürthle, K., 1894. Beiträge zur Kenntnis des Sekretionsvorganges in der Schilddrüse. Arch. f. d. gesam. Phys. d. Mensch. u. d. Tiere, Bd. 56.

Kendall, E. C., 1919. Isolation of the iodine compound which occurs in the thyroid. First paper. The Jour. of biol. Clem., Vol. 39, No. 1.

Kendall, E.C., \& Osterberg, A.E., 1919. The chemical identification of thyroxim. Second paper. 'The Jour. of biol. Chem., Vol. 40, No. 2.

Langendorff, 0, 1889. Beiträge zur Kenntnis der Schilddrüse. Arch. f. Anat. u. Phys., (Phys. Abt.) Suppl. Bd.

Langendorff, O., 1889. Ältere und neuere Ansichten über die Schilddrüse. Biologisches Zientralblatt, Bd. 9.

Lobenh of fer, 1909. Beiträge zur Lehre der Sekretion in der Struma. Mitt. aus den Grenzgeb. der Med. u. Clirurg., Bd. 20.

Matsunaga, 1909. Die parenchymatösen Lymplbahnen der Thyreoidea und ihre Sekretion. Arcl,. f. Auat. u. Entwicklungsgesch., Jahrgang 1909. 
Maurer, F., 1917. Die morphologische Benrteilung der Epithelkörpercheu und anderer Drüsen mit innerer Sekretion. Jenaische Zeitschrift f. Naturwissenscliaft, Bd. 55, H. 1.

I a was, Jacques, 1911. Sur la structure du protoplasma des cellules épitjéliales du corps thyroide de quelques mammiféres. Le chondriosome et les phénomènes de sécrétion. Bibliogr. anat., T. 21, Fasc. 5, out of the Jaliresberichte der Anatomie und Entwicklungsgeschte.

M üller, L. R., 1896. Beitrüge zur Histologie der normalen und erkranliten Schilddriise. Beiträge zur path. Anat. u. zur allg. Path., Bd. 19.

Prenant, A. et Bouin, P., 1911. Traité d'histologie. Glande thyroide.

Schmid, E., 1896. Der Sekretionsvorgang in der Schilddrïse. Archr. f. mili Anat., Bd. 47.

Schultze, 0., 1911. Über die Genese der Granula in den Driisenzellen: Anạt. Anz., Bd. 38.

Sobotta, J., 1915. Anatomie der Schilddrüse. Handbuch der Anatomie des Menschen. Karl von Bardeleben.

Takagi, K., 1920. Zur Kenntuis der Pankreassekretion. Festschrift fïr Ailuiko Sa ta zu seinem 25 jährigen Professorenjubiläum.

Zielinska, M., 1894. Beitrïge zur Kenutnis der normalen und strumösen Schilddrïse des Menschen unil des Hundes. Arch. f. patl. Anat. u. Phys. u. f. kl. Med., Bd. 136.

'Zimmermann, K. W., 1898. Beiträge zur Kemitnis einiger Drüsen und Epithelien. Arch. f. mik. Anat., Bd. 52. 


\section{Explanation of Plates.}

All the figures have been drawn at the height of the desk, with an Abbe's apparatus, under the same magnifying power-Zeiss' apochromat homogene immersion $2 \mathrm{~mm}$. (n.A. 1.4), compensations okular 18, tube length $160 \mathrm{~mm}$.- from preparations fixed by Meves' solution and stained by Heidenbain's ironalum-liaematoxyliu.

\section{Explanation of Figures.}

Fig. 1 to 28 illustrate the follicular epithelium-cells.

Fig. 1 to 7 the chief-cells of a dog abont 1-year-old.

Fig. 8 to 15 the chief-cells of a 8-days-old puppy.

Fig. 16 to 24 the colloid-cells of a dog a hont 1-year-old.

Fig. 25 to 28 the colloid-cells of a 3-days-old puppy.

Fig. 29 to 34 illustrate the interfollicular epithelium-cells.

Fig. 29 to 32 from a dog alout 1-year-old.

Fig. 33 from a 5-days-old puppy.

Fig. 34 from a 3-days-old puppy.

A fuller explanation is given in the text. 


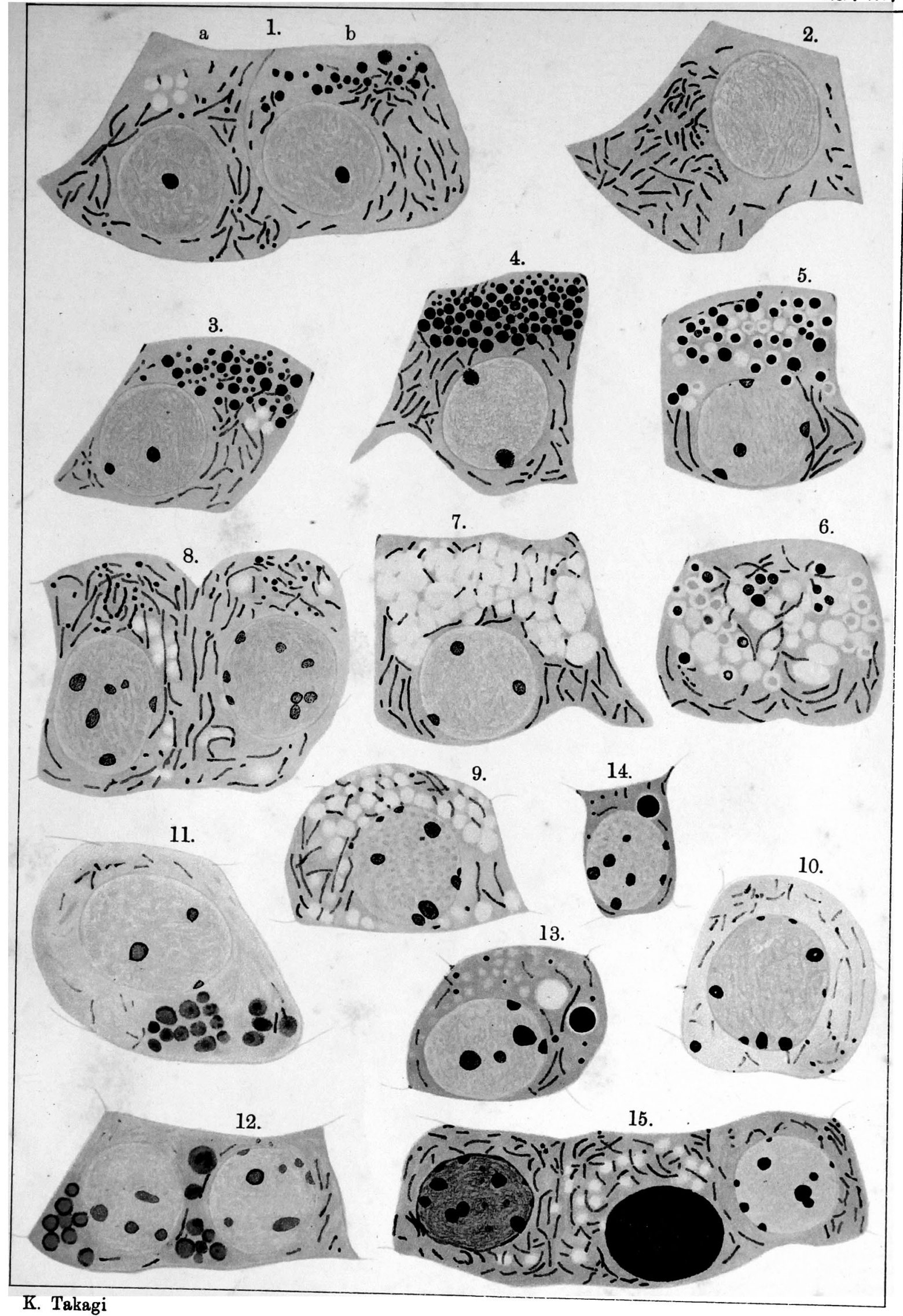



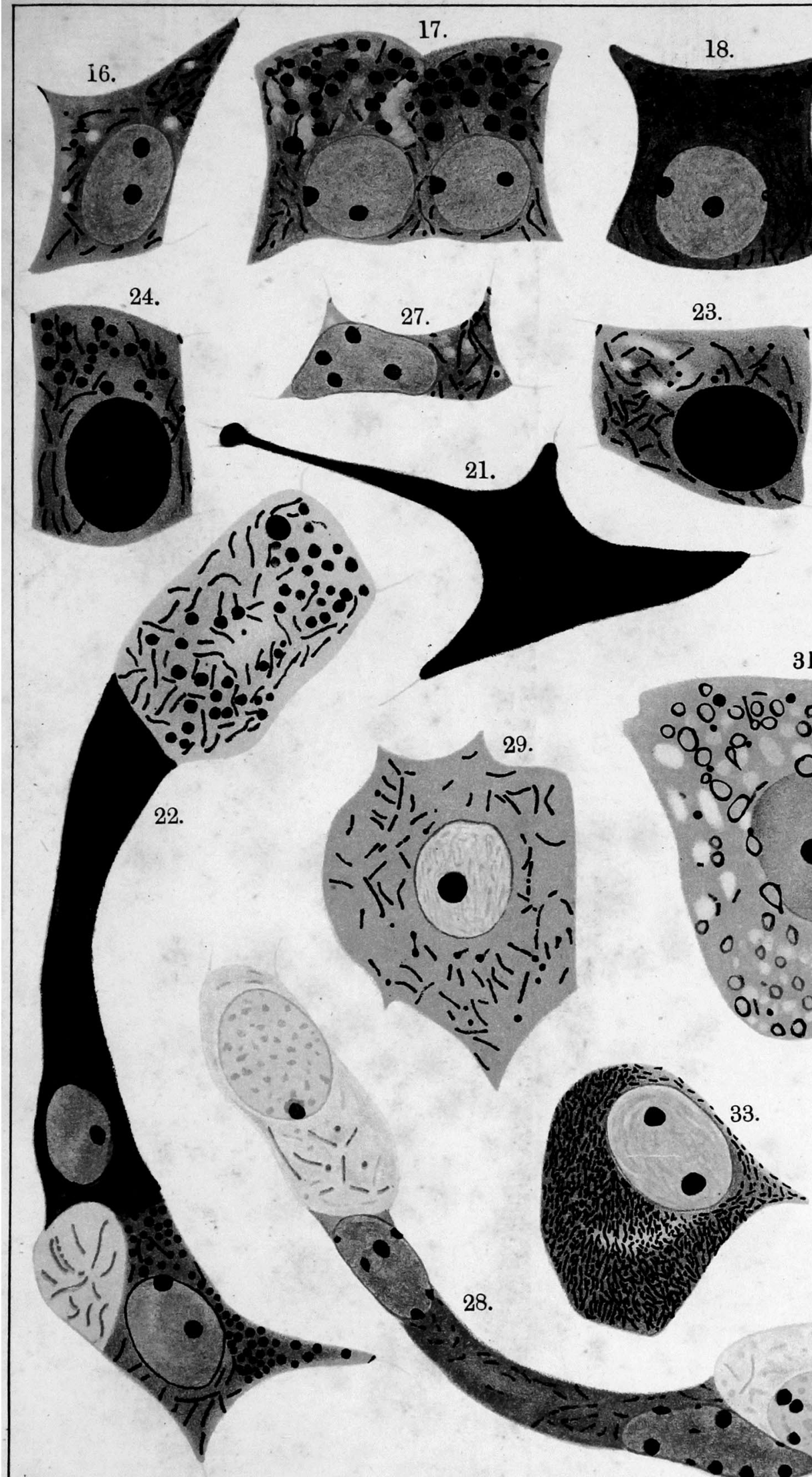

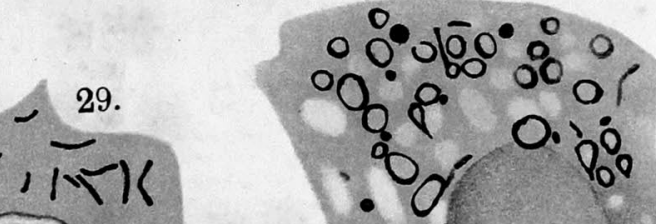
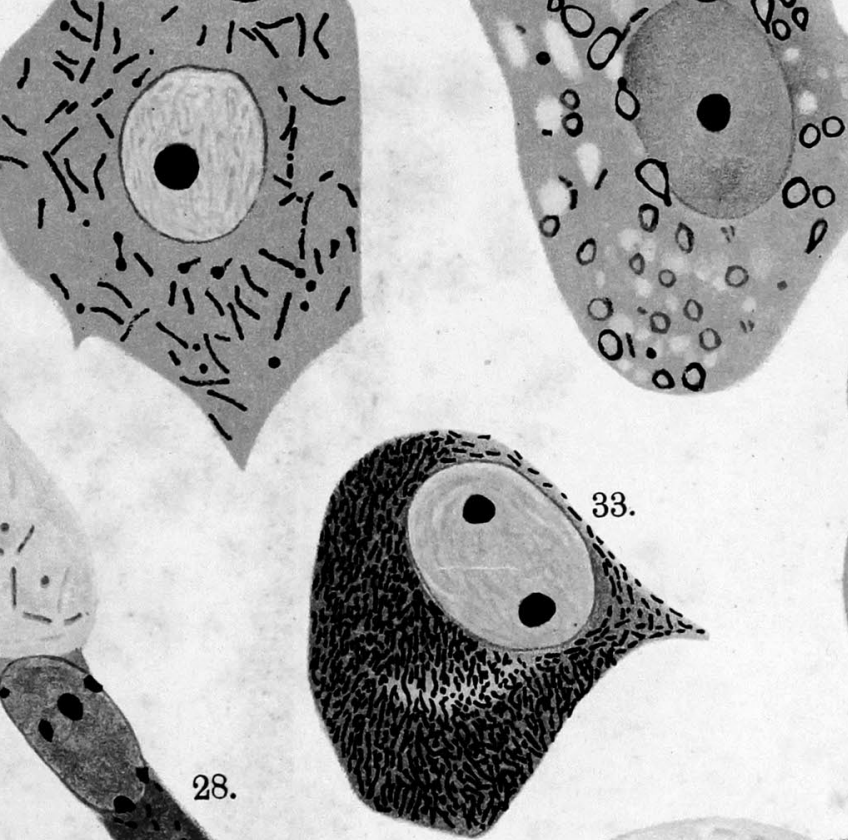

28.
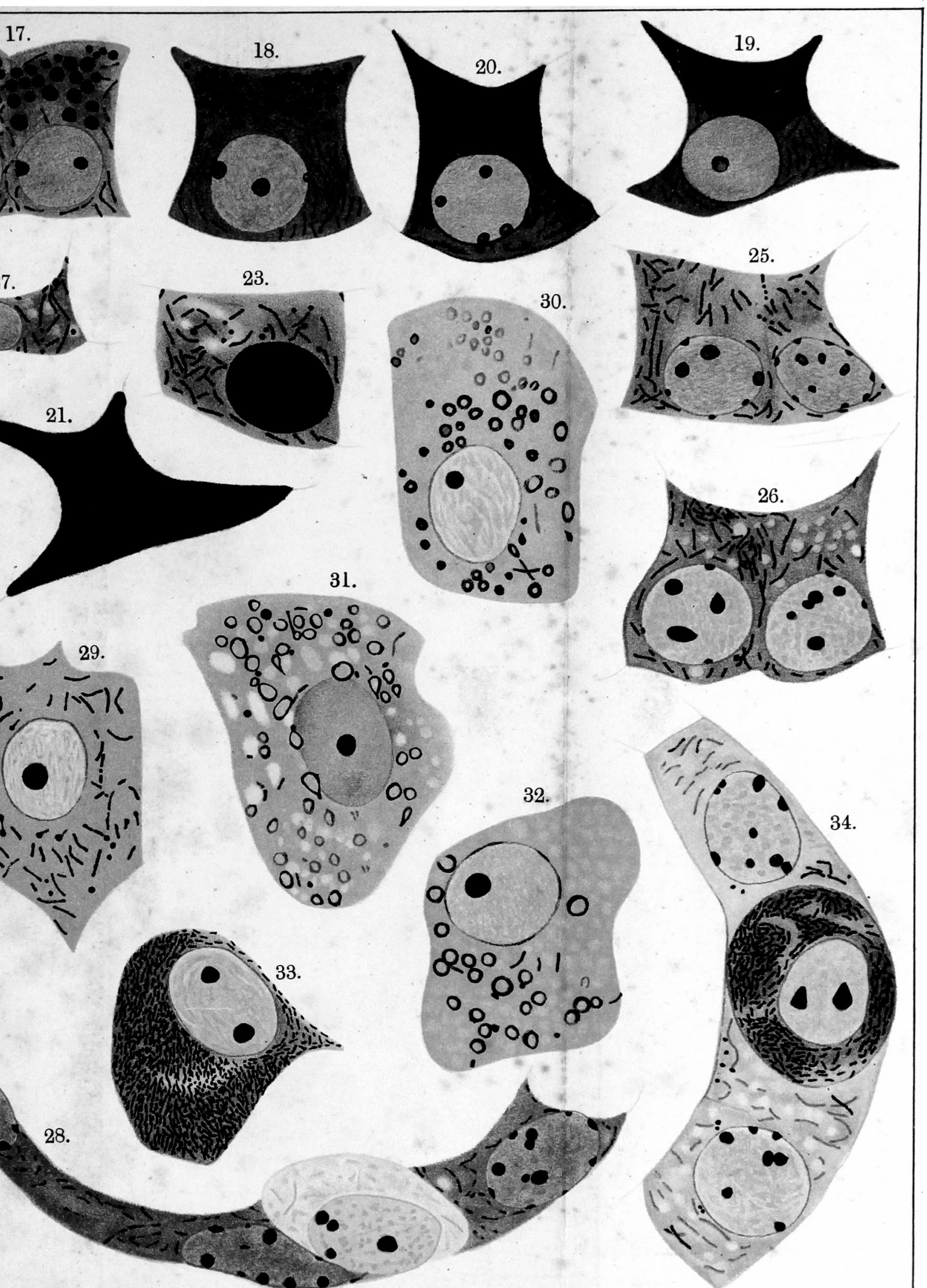

K. Takagi 